\title{
Thermosensitive H1 Plasmids Determining Citrate Utilization
}

\author{
By H. WILLIAMS SMITH, Z. PARSELL AND P. GREEN \\ Houghton Poultry Research Station, Houghton, Huntingdon, \\ Cambridgeshire PE17 2DA
}

(Received 21 April 1978)

\begin{abstract}
Twelve thermosensitive H1 plasmids from strains of Salmonella typhi that had caused outbreaks of chloramphenicol-resistant typhoid fever in Vietnam, Thailand and India mediated citrate utilization $\left(\mathrm{Cit}^{+}\right.$) in a prototrophic Escherichia coli $\mathrm{K} 12$ strain but not in the $S$. typhi strains from which they were derived. Four $\mathrm{H} 1$ plasmids from a similar outbreak in Mexico differed from the Far Eastern plasmids in not mediating citrate utilization but in mediating mercury resistance. H1 plasmids resembling the Far Eastern and the Mexican plasmids in regard to citrate utilization and mercury resistance were found in sewage in Britain. Citrate utilization was transferred to eight pathogenic strains of $E$. coli and to one strain each of Shigella flexneri and Shigella sonnei. Cultures of $\mathrm{Cit}^{+}$bacteria grew more rapidly in citrate media at $28{ }^{\circ} \mathrm{C}$ than at $37^{\circ} \mathrm{C}$. Plasmid mutants that were more efficient at utilizing citrate were present in all such cultures - they grew equally well or better at $37^{\circ} \mathrm{C}$ than at $28^{\circ} \mathrm{C}$. None of 222 strains of $E$. coli or Shigella that contained a variety of different plasmids were able to utilize citrate. This property was not transferred to the prototrophic E. coli $\mathrm{K} 12$ strain from Citrobacter (3 strains), Salmonella (39 strains), Proteus (44 strains), Klebsiella pneumoniae (33 strains) or Pseudomonas aeruginosa (44 strains).
\end{abstract}

\section{INTRODUCTION}

Recently, enterobacterial strains and specimens of sewage and river water were searched for thermosensitive (ts) antibiotic resistance plasmids (Smith et al., 1978). The 73 that were found were examined to see whether they belonged to compatibility groups $\mathrm{H} 1$ and $\mathrm{H} 2$ (Anderson, 1975) because plasmids of these groups are known to be thermosensitive (Smith, 1974; Anderson, 1975); 12 were of group $\mathrm{H} 1$ and 58 of group H2. These plasmids were then transferred to a prototrophic Escherichia coli $\mathrm{K} 12$ strain and the resulting $\mathrm{R}^{+}$forms were examined to see whether they had acquired characters other than antibiotic resistance. Three of the 12 forms with $\mathrm{H} 1$ plasmids in them had acquired the ability to utilize citrate as sole energy source $\left(\mathrm{Cit}^{+}\right)$. So, too, had a form of the $E$. coli $\mathrm{K} 12$ strain harbouring an $\mathrm{H} 1$ plasmid determining resistance to chloramphenicol, tetracyclines, streptomycin, spectinomycin and sulphonamides that had been obtained from a Salmonella typhi strain incriminated in an outbreak of typhoid fever in Vietnam (Butler et al., 1973); this plasmid had been included in the investigation for comparison with the other ts plasmids. As a collection of $\mathrm{H} 1$ plasmids was available that had been obtained from $S$. typhi causing other outbreaks of typhoid fever in Vietnam and also in Thailand, India and Mexico, it was decided to obtain more information on transmissible citrate-utilizing ability; the results of the investigation are reported in this paper. 


\section{METHODS}

Bacterial strains and plasmids. Of 16 strains of $S$. typhi possessing ts $\mathrm{H} 1$ plasmids determining resistance to chloramphenicol, tetracyclines, streptomycin, spectinomycin and sulphonamides that were studied, four were from cases of typhoid fever in Mexico (Center for Disease Control Weekly Report, 1972), two from cases in India (Paniker \& Vimala, 1972), four from cases in Vietnam (Butler et al., 1973) and six from cases in Thailand (Lampe et al., 1974). For subsequent examination these plasmids, like the $12 \mathrm{HI}$ plasmids from the ts plasmid survey, were transferred to an antibiotic-sensitive $\mathrm{lac}^{+}$prototrophic $\mathrm{E}$. coli $\mathrm{K} 12$ strain, using a minimum salts agar medium containing lactose and tetracycline for selecting the $\mathbf{R}^{+}$recipient organisms. The previous bacterial hosts of the three plasmids from the survey that were $\mathrm{Cit}^{+}$were not known. They had been obtained from different specimens of untreated sewage in Britain: two determined resistance to neomycin and tetracyclines and one to tetracyclines only.

The other bacterial strains studied were stock cultures of $E$. coli, Citrobacter, Salmonella, Proteus, Klebsiella pneumoniae and Pseudomonas aeruginosa maintained in this laboratory on Dorset egg medium at $5^{\circ} \mathrm{C}$; they are believed to be epidemiologically unrelated.

Citrate utilization. The standard nethod of determining ability to use citrate as sole energy source was to inoculate approximately $10^{8}$ viable organisms from washed broth cultures in duplicate on to plates of Simmons citrate agar (Difco B91). One set of plates was incubated at $28^{\circ} \mathrm{C}$ and one at $37^{\circ} \mathrm{C}$. The plates were examined daily for $4 \mathrm{~d}$ and the sizes of the colonies that grew on them were noted. When growth factorrequiring organisms were tested, the medium was supplemented with the necessary factor at $30 \mu \mathrm{g} \mathrm{ml}^{-1}$, e.g. for Salmonella typhi it was supplemented with tryptophan, and for Shigella sonnei and Proteus spp. it was supplemented with nicotinic acid. The Oxoid formulation (CM155) of Siminons citrate agar was also tested but its routine use was abandoned because at $28^{\circ} \mathrm{C} \mathrm{Cit}+$ colonies grew more poorly on it than on the medium of Difco formulation. The growth of some strains was also studied in a liquid medium, Koser citrate medium (Difco B15). In routine tests, the tubes of media were inoculated with approximately $10^{4}$ viabie organisms from washed broth cultures, incubated at $37{ }^{\circ} \mathrm{C}$ and at $28{ }^{\circ} \mathrm{C}$ and examined daily for visual evidence of bacterial growth. In experiments with the prototrophic $E$. coli $\mathrm{k} 12$ strain, the inocula employed were a 10 -fold decreasing series from $10^{8}$ to $10^{2}$ viable organisms.

Sensitivity tests. Antibiotic sensitivity was tested by the disc diffusion method; sensitivity to inorganic compounds was tested by the strip diffusion method (Smith et al., 1978). For detecting resistance to sodium arsenite, plasmids were first implanted in a Salmonella typhimurium strain because E. coli $\mathrm{k} 12$ is moderately resistant to this compound (Smith, 1978).

Identification of bacterial strains possessing transmissible citrate-utilizing ability and antibiotic resistance. Nutrient broth was inoculated with $0.2 \mathrm{ml}$ each of broth cultures of the strain to be tested and of a spontaneous chromosomal mutant of the $E$. coli $\mathrm{k} 12$ strain that was resistant to sodium nalidixate $\left(\mathrm{Nal}{ }^{\mathrm{r}}\right)$ and rifampicin (Rifr). After incubation at $28{ }^{\circ} \mathrm{C}$ for $24 \mathrm{~h}$, the mixed culture was inoculated on to plates of culture media containing sodium nalidixate $\left(20 \mu \mathrm{g} \mathrm{ml}^{-1}\right)$, if the prospective donor strain was E. coli, Proteus or Salmonella, or rifampicin $\left(80 \mu \mathrm{g} \mathrm{ml}^{-1}\right)$, if it was Klebsiella pneumoniae or Pseudomonas aeruginosa. For detecting transfer of antibiotic resistance, the medium was MacConkey agar containing an additional antibiotic $\left(20 \mu \mathrm{g} \mathrm{ml}^{-1}\right)$ to which the donor, but not the recipient, was resistant. For detecting transfer of ability to utilize citrate, the medium was citrate agar. The plates of MacConkey agar were incubated at $37^{\circ} \mathrm{C}$ for $24 \mathrm{~h}$; those of citrate agar were incubated at $28^{\circ} \mathrm{C}$ and at $37^{\circ} \mathrm{C}$ for $4 \mathrm{~d}$. This procedure was also used to detect strains that could receive plasmids determining antibiotic resistance and citrate-utilizing ability; the prospective recipient strains were $\mathrm{Nal}^{\mathrm{r}}$ mutants and the donor strain was the prototrophic $E$. coli $\mathrm{K} 12$ strain. To ascertain whether both antibiotic resistance and citrate-utilizing ability had been acquired by recipient organisms, either colonies that had grown on one of the two kinds of selection media were tested to see whether they would grow on the other kind, or the mating cultures were inocuiated on to plates of MacConkey medium containing the antibiotic to which the recipient strain was resistant and these plates, after incubation, were replica-plated (Lederberg \& Lederberg, 1952) on to the two kinds of selection media.

Identification of plasmids that were thermosensitive and that belonged to compatibility group H1. This was achieved hy the methods previously described (Smith et al., 1978).

Attempts to obtain citrate-utilizing mutants of the prototrophic E. coli $\mathrm{K} 12$ strain. Approximately $10^{11}$ viable organisms from washed broth cultures were inoculated on to two sets of plates of citrate agar and into two sets of tubes of liquid citrate medium. One set of each was incubated at $37^{\circ} \mathrm{C}$ and the other at $28^{\circ} \mathrm{C}$ for $4 \mathrm{~d}$. The plates were then examined for the presence of colonies and the tubes were subcultured lightly into tubes of fresh liquid citrate medium and examined, after incubation, for visual evidence of bacterial growth.

Attempts to obtain stable citrate-utilizing strains from unstable strains. Organisms picked from colonies on plates of citrate agar were submitted to five serial passages, each of $24 \mathrm{~h}$, in liquid citrate medium at $28^{\circ} \mathrm{C}$ and at $37 \mathrm{C}$. The final passaged culture was then re-inoculated on to citrate agar, a colony was picked after incubation and the process was repeated. 
Table 1. Citrate-utilizing ability and mercury resistance of forms of the prototrophic E. coli $\mathrm{K} 12$ strain possessing $H 1$ antibiotic resistance plasmids from different sources

\begin{tabular}{|c|c|c|c|c|}
\hline \multirow[b]{2}{*}{$\begin{array}{l}\text { No. of } \\
\text { forms }\end{array}$} & \multicolumn{2}{|c|}{ Plasmids possessed } & \multirow[b]{2}{*}{$\begin{array}{l}\text { Citrate } \\
\text { utilization }\end{array}$} & \multirow[b]{2}{*}{$\begin{array}{l}\text { Mercury } \\
\text { resistance }\end{array}$} \\
\hline & Source* & $\begin{array}{c}\text { Antibiotic } \\
\text { resistance mediated } \dagger\end{array}$ & & \\
\hline 6 & $\begin{array}{l}\text { Salmonella typhi from } \\
\text { Thailand }\end{array}$ & $\mathrm{CmTcSmSpcSu}$ & + & - \\
\hline 4 & S. typhi from Vietnam & $\mathrm{CmTcSmSpcSu}$ & + & - \\
\hline 2 & S. typhi from India & $\mathrm{CmTcSmSpcSu}$ & + & - \\
\hline 4 & S. typhi from Mexico & $\mathrm{CmTcSmSpcSu}$ & - & + \\
\hline 3 & Sewage & $\mathrm{TcNm}$ or $\mathrm{Tc}$ & + & - \\
\hline 1 & River water & $\mathrm{CmSu}$ & - & + \\
\hline 5 & River water & $\mathrm{CmApSu}$ or Tc & - & - \\
\hline 1 & Sewage & Tc & - & - \\
\hline 2 & Pig Escherichia coli & Tc & - & - \\
\hline
\end{tabular}

* Except where stated, all the sources were in Britain.

$\dagger \mathrm{Cm}$, Chloramphenicol; Tc, tetracycline; Sm, streptomycin; Spc, spectinomycin; Ap, ampicillin; $\mathrm{Su}$, sulphonamides; $\mathrm{Nm}$, neomycin.

Plasmid removal. This was achieved by submitting strains to three serial passages in nutrient broth at $44^{\circ} \mathrm{C}$. After the final passage, the cultures were replica-plated on to MacConkey agar containing chloramphenicol or tetracycline (each $20 \mu \mathrm{g} \mathrm{ml}^{-1}$ ) and on to citrate agar.

\section{RESULTS}

Citrate utilization and other characteristics mediated by $\mathrm{H} 1$ plasmids

The citrate-utilizing ability and mercury resistance of the forms of the prototrophic $E$. coli K12 strain to which the $16 \mathrm{H} 1$ antibiotic resistance plasmids of the $S$. typhi strains and the 12 from the ts plasmid survey had been transferred are shown in Table 1; none of them were resistant to sodium arsenite or potassium tellurite. The forms possessing the plasmids of the $S$. typhi strains isolated in the Far Eastern countries (Thailand, Vietnam and India) differed from those possessing the plasmids of the Mexican $S$. typhi strains in that they utilized citrate but were not mercury resistant; three forms possessing plasmids from the ts plasmid survey resembled those possessing the Far Eastern $S$. typhi plasmids and one resembled those possessing the Mexican S. typhi plasmids.

Transfer of citrate-utilizing ability from the $15 \mathrm{Cit}^{+} E$. coli $\mathrm{K} 12$ forms, like that of their antibiotic resistance determinants, was thermosensitive, and the genetic elements responsible for its transfer belonged to compatibility group $\mathrm{H} 1$.

\section{Growth of citrate-utilizing $E$. coli $\mathrm{K} 12$ in culture media containing citrate}

On citrate agar. No difference was detected in cultural characteristics between the forms of the $E$. coli $\mathrm{K} 12$ strain harbouring the 15 plasmids that mediated citrate utilization. Growth on plates of citrate agar at $28^{\circ} \mathrm{C}$ was clearly visible after $2 \mathrm{~d}$ incubation by which time the colour of the medium had changed from green to blue; after $4 \mathrm{~d}$ incubation wellseparated colonies were 1 to $1.5 \mathrm{~mm}$ in diameter. The $15 \mathrm{Cit}^{+}$forms grew much more poorly at $37{ }^{\circ} \mathrm{C}$; after $4 \mathrm{~d}$ incubation most of the colonies were just visible to the naked eye. However, within $2 \mathrm{~d}$ incubation, 50 to 200 large mutant colonies ( 1.5 to $2 \mathrm{~mm}$ diam.) were present on the plates inoculated with all $15 \mathrm{Cit}^{+}$forms, the colonies being even larger after $4 \mathrm{~d}$ incubation (Fig. 1); for convenience, these mutants are referred to as $\mathrm{Cit}^{++}$. They were also present on plates incubated at $28^{\circ} \mathrm{C}$ but were more difficult to discern because of the heavy surrounding growth of $\mathrm{Cit}^{+}$organisms. Subcultures of $\mathrm{Cit}^{++}$organisms grew more rapidly at $37^{\circ} \mathrm{C}$ than at $28^{\circ} \mathrm{C}$. They were, however, unstable in that they usually yielded a majority 


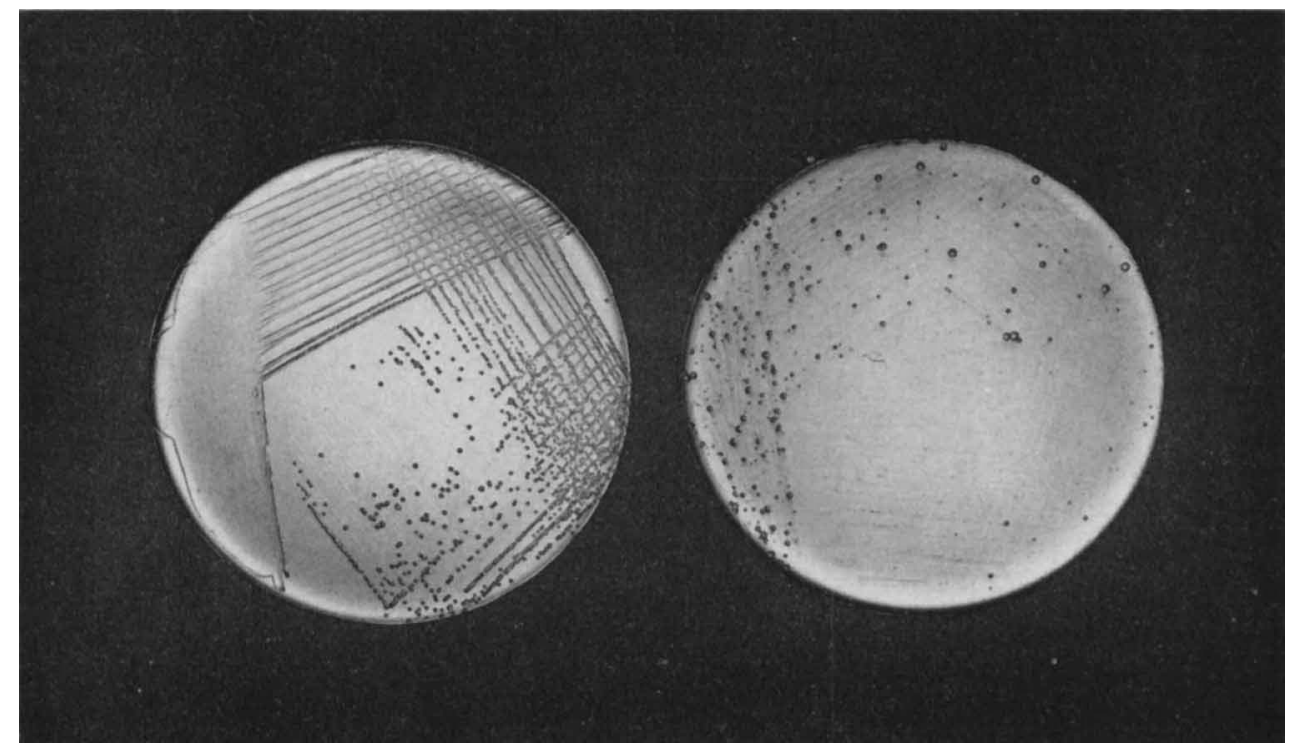

Fig. 1. Two plates of citrate agar inoculated in a similar manner with a prototrophic Escherichia coli $\mathrm{K} 12$ strain harbouring a plasmid determining citrate utilization obtained from a strain of Salmonella typhi. The bacterial growth on the left plate, which had been incubated at $28{ }^{\circ} \mathrm{C}$ for $3 \mathrm{~d}$, consists of very many citrate-utilizing colonies $\left(\mathrm{Cit}^{+}\right)$and a small number of more efficient citrate-utilizing mutants $\left(\mathrm{Cit}^{++}\right)$. Only the $\mathrm{Cit}^{++}$mutants are discernible on the right plate, which had been incubated for $3 \mathrm{~d}$ at $37^{\circ} \mathrm{C}$.

of colonies on citrate agar that were $\mathrm{Cit}^{+}$. For example, after four serial passages in nutrient broth at $37{ }^{\circ} \mathrm{C}$, the ratios of $\mathrm{Cit}^{++}$to $\mathrm{Cit}^{+}$organisms in cultures of four forms of the $E$. coli $\mathrm{K} 12$ strain harbouring different citrate-utilizing plasmids were approximately $1: 5,1: 10$, $1: 100$ and $1: 1000$. Three of these four plasmids were from $S$. typhi strains isolated in Vietnam, Thailand and India; the fourth was one of those found in the ts plasmid survey. (These are the four plasmids referred to in subsequent experiments.) It was only possible to obtain a stable $\mathrm{Cit}^{++}$culture from one of the four forms.

The $S$. typhi strains from which 12 of the $15 \mathrm{Cit}^{+}$plasmids had been obtained would not grow on citrate agar, even when tryptophan was added; they grew on the tryptophansupplemented medium when the citrate was replaced by glucose.

In liquid medium. The tubes of liquid citrate medium inoculated with a 10 -fold decreasing series from $10^{8}$ to $10^{2}$ viable organisms of the four forms of the E. coli $\mathrm{K} 12$ strain containing different citrate-utilizing plasmids were all turbid with bacterial growth after $6 \mathrm{~d}$ incubation at $28{ }^{\circ} \mathrm{C}$; a slight degree of bacterial growth was observed after $3 \mathrm{~d}$ incubation in the tubes inoculated with $10^{4}$ or more viable organisms. Tubes examined when the amount of bacterial growth in them was small contained only $\mathrm{Cit}^{+}$organisms; when the growth became heavy they contained mainly Cit ${ }^{++}$organisms. After $6 \mathrm{~d}$ incubation at $37^{\circ} \mathrm{C}$, usually only the tubes that had received an inoculum of $10^{4}$ or more organisms were turbid; there was little or no evidence of growth in any of the tubes after $3 \mathrm{~d}$ incubation. With continued incubation all the tubes became turbid, the principal organisms they contained being $\mathrm{Cit}^{++}$.

It was not possible to obtain citrate-utilizing mutants of the E. coli K12 parent strain by cultivation on citrate agar or in the liquid citrate medium. 


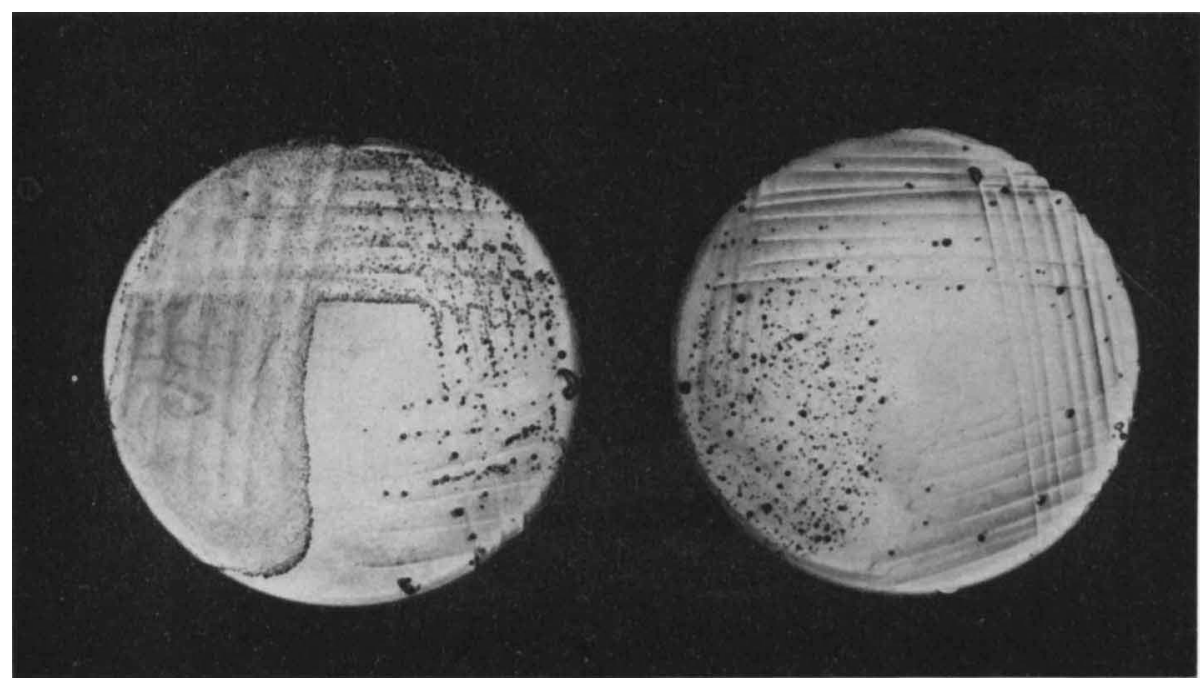

Fig. 2. Two plates of nalidixate-containing citrate agar inoculated with a mating culture of an $E$. coli $\mathrm{K} 12$ donor strain harbouring a plasmid determining citrate utilization and a $\mathrm{Nal}^{\mathrm{r}} E$. coli $\mathrm{K} 12$ recipient strain. The donor organisms on the right plate were normal citrate-utilizing organisms $\left(\mathrm{Cit}^{+}\right)$and those on the left plate were the more efficient mutants $\left(\mathrm{Cit}^{++}\right)$. The plates were incubated at $37^{\circ} \mathrm{C}$ for $3 \mathrm{~d}$. Many more recipient colonies of the $\mathrm{Cit}^{++}$variety are present on the left than on the right plate.

\section{Transfer of citrate-utilizing ability between $E$. coli $\mathrm{K} 12$ organisms: association between} citrate-utilizing and antibiotic resistance genes

In matings between cultures prepared from $\mathrm{Cit}^{+}$organisms and from $\mathrm{Cit}^{++}$organisms of the four forms of the $E$. coli $\mathrm{K} 12$ strain harbouring the different citrate-utilizing plasmids and a Nalr mutant of this strain, approximately $10 \%$ of the organisms of the latter acquired the plasmids. The proportions of $\mathrm{Cit}^{++}$to $\mathrm{Cit}^{+}$recipient organisms in the mating cultures $\mathrm{n}$ which the donor organisms were $\mathrm{Cit}^{++}$were about 1:0,1:10,1:10 and 1:1000. The proportions in the four mating cultures in which the donors were $\mathrm{Cit}^{+}$, however, were similar to those in the donor cultures themselves, i.e. about 1:106 (Fig. 2). Replica-plating of the mating cultures prepared in these experiments revealed that the organisms of the recipient strain were either $\mathrm{Cit}^{+}$(or $\mathrm{Cit}^{++}$) $\mathrm{R}^{+}$or $\mathrm{Cit}^{-} \mathrm{R}^{-}$. In plasmid removal studies, 3 to $6 \%$ of the organisms of the donor strains used in these experiments lost both their citrateutilizing genes and their antibiotic resistance genes; no organisms that had lost one or other were detected. In all other experiments in which the 15 citrate-utilizing antibiotic resistance $\mathrm{H} 1$ plasmids were transmitted between $E$. coli $\mathrm{K} 12$ strains, there was also no evidence of segregation of the citrate-utilizing or the antibiotic resistance genes.

\section{Transfer of citrate-utilizing ability from E. coli $\mathrm{K} 12$ to other $E$. coli strains and to Shigella strains}

The ability to utilize citrate was transferred from the four forms of the E. coli $\mathrm{K} 12$ strain possessing the different citrate-utilizing plasmids to $\mathrm{Nal}^{\mathrm{r}}$ mutants of two $E$. coli strains that had caused generalized infections in human beings (O18: K1:H7 and $0129: \mathrm{K}$ ?:H4), two human enteropathogenic strains $\left(\mathrm{O} 78: \mathrm{H} 11\right.$ and $\left.\mathrm{O} 26: \mathrm{K} 60: \mathrm{H}^{-}\right)$, two piglet enteropathogenic strains (O141:K85,88 and $\left.09: \mathrm{K} 103: \mathrm{H}^{-}\right)$, two calf enteropathogenic strains (O8: K85,99 and 09:K35,99), a Shigella flexneri strain and of a Shigella sonnei strain, the only strains to which transmission was attempted. All of 240 recipient isolates selected from the 12 matings (20 from each) employing the $018: \mathrm{K} 1: \mathrm{H} 7$, the $\mathrm{O} 9: \mathrm{K} 103: \mathrm{H}^{-}$and the $09: \mathrm{K} 35,99$ strains were $\mathrm{Cit}^{+} \mathrm{R}^{+}$. So were most of the 96 isolates selected from these matings (eight from each) 
because they were $\mathrm{Cit}^{+}$; however, seven from the matings with the $\mathrm{O} 18: \mathrm{K} 1: \mathrm{H} 7$ strain and one from each of the matings with the other two recipient strains were $\mathrm{Cit}^{+} \mathrm{R}^{-}$and possessed conjugative ability. All of $56 \mathrm{R}^{+}$recipient isolates selected from the 28 matings (two from each) in which the other seven strains were employed were $\mathrm{Cit}^{+} \mathbf{R}^{+}$; so were $56 \mathrm{Cit}^{+}$isolates selected from these matings (two from each).

As for transfers between the $E$. coli $\mathrm{K} 12$ strains, a much higher proportion of the recipient organisms of the eight pathogenic E. coli strains and the two Shigella strains were of the $\mathrm{Cit}^{++}$mutant variety when the $E$. coli $\mathrm{K} 12$ donor culture was prepared from $\mathrm{Cit}^{++}$organisms rather than from $\mathrm{Cit}^{+}$organisms. Cultures of $\mathrm{Cit}^{+}$organisms of the 10 strains contained similar proportions of $\mathrm{Cit}^{++}$organisms as was found when $E$. coli $\mathrm{K} 12$ was the recipient, although, in general, the $\mathrm{Cit}^{+}$organisms of these strains grew less well on citrate agar at $28{ }^{\circ} \mathrm{C}$ than did $E$. coli $\mathrm{K} 12 \mathrm{Cit}^{+}$organisms but always better than they did at $37^{\circ} \mathrm{C}$. Neither $\mathrm{Cit}^{+}$nor $\mathrm{Cit}^{++}$cultures grew as luxuriantly on citrate agar as Salmonella typhimurium, Klebsiella, Proteus or Pseudomonas aeruginosa strains. For example, at $37{ }^{\circ} \mathrm{C}$ an incubation period of $4 \mathrm{~d}$ was usually required before colonies of $\mathrm{Cit}^{++}$organisms became as large as colonies of $S$. typhimurium that had been incubated for $2 \mathrm{~d}$. From an inoculum of $10^{4}$ viable organisms most of the $\mathrm{Cit}^{+}$cultures produced visible growth in liquid citrate medium in 3 to $5 \mathrm{~d}$ at $28{ }^{\circ} \mathrm{C}$ and in 8 to $12 \mathrm{~d}$ at $37^{\circ} \mathrm{C}$; the $\mathrm{Cit}^{++}$cultures usually produced visible growth in 2 to $3 \mathrm{~d}$ at $28^{\circ} \mathrm{C}$ and $37^{\circ} \mathrm{C}$.

\section{A search for citrate-utilizing ability in plasmid-containing strains of E. coli and Shigella}

None of 222 strains of $E$. coli, three strains of Shigella dysenteriae or two strains of Shigella sonnei, all of which harboured temperature-tolerant plasmids, grew on citrate agar incubated at $28^{\circ} \mathrm{C}$ and $37^{\circ} \mathrm{C}$. About 100 of the plasmids provided the same pattern of antibiotic resistance as that provided by the plasmids of the $S$. typhi strains. Others mediated production of colicin, haemolysin, enterotoxin, K88, K99 and Vir antigens and lactose, sucrose and raffinose utilization.

\section{Attempts to transmit citrate-utilizing ability from strains of bacterial genera possessing this property}

No transfer of citrate-utilizing ability to the E. coli 12 strain was detected from Citrobacter (3 strains), Salmonella (39 strains), Klebsiella pneumoniae (33 strains), Proteus (44 strains) or Pseudomonas aeruginosa (44 strains).

\section{DISCUSSION}

The results suggest that plasmid-borne ability to utilize citrate is relatively rare and may be principally confined to $\mathrm{Hl}$ plasmids. Even so, the fact that plasmids possessing this characteristic were found in sewage in Britain as well as in $S$. typhi strains isolated in the Far Eastern countries (Vietnam, Thailand and India) reveal that it is widely distributed in nature.

Although it seemed probable at one time that the same $\mathrm{H} 1$ plasmid was responsible for the chloramphenicol resistance of the $S$. typhi strains causing the outbreaks of typhoid fever in the Far Eastern countries and in Mexico, it is now clear that this is not so; not only were the Mexican plasmids we examined $\mathrm{Cit}^{-}$but they also mediated mercury resistance, a property not shared by the Far Eastern plasmids. The Far Eastern plasmids had been found in several different phage types of $S$. typhi whereas the Mexican ones were in the same phage type (Anderson, 1975). It is of interest that $\mathrm{Hl}$ plasmids resembling both the Far Eastern and the Mexican ones in regard to citrate utilization and mercury resistance were present in the collection obtained from British sewage, but they differed in regard to the kinds of antibiotic resistance they provided. However, before one can be certain on all these aspects of plasmid relationship, DNA studies would be required to establish that the antibiotic resistance genes and the citrate-utilizing genes, and the mercury resistance genes for that matter, 
are located in the same plasmid. Most of the evidence presented in this paper strongly suggests that the antibiotic resistance genes and the citrate-utilizing genes are so located but it must be borne in mind that in some of the experiments in which the plasmids were transferred to wild strains of $E$. coli, a small number of recipient organisms were isolated that possessed the citrate-utilizing genes but not the antibiotic resistance genes; there can, of course, be explanations for this other than that the genes are located on separate plasmids.

Because the forms of the $E$. coli $\mathrm{K} 12$ strain containing the 15 Cit plasmids that were identified grew in a similar and highly characteristic manner on citrate agar, it seems likely that the genes determining citrate utilization in all 15 were identical. Although neither they nor the pathogenic E. coli or Shigella strains in which they had been implanted grew as luxuriantly as Salmonella, Proteus, Klebsiella and Pseudomonas, they utilized citrate sufficiently to be classified as citrate-positive in routine tests. In the $S$. typhi strains from which 12 of the 15 had been obtained, though, the plasmids failed to express citrate utilization. Presumably, this is due to some metabolic difference between the $S$. typhi strains and the $E$. coli and Shigella strains. Host differences of this nature were also observed in regard to two plasmids determining substrate utilization studied by Smith et al. (1978) - a $\mathrm{lac}^{+}$prototrophic E. coli $\mathrm{K} 12$ strain possessing these plasmids utilized sucrose but not raffinose whereas a $S$. typhimurium strain possessing them utilized sucrose and raffinose.

The unstable mutants found in all cultures harbouring plasmids mediating citrate utilization and referred to, for convenience, as $\mathrm{Cit}^{++}$differed from their parent organisms in at least two respects - in utilizing citrate more efficiently and in doing it equally well or better at $37^{\circ} \mathrm{C}$ than at $28{ }^{\circ} \mathrm{C}$. Nevertheless, because cultures of recipient organisms from matings with $\mathrm{Cit}^{++}$donors contained many more $\mathrm{Cit}^{++}$organisms than similar cultures from matings in which the donors were $\mathrm{Cit}^{+}$, it is apparent that the mutation to $\mathrm{Cit}^{++}$is solely a function of the plasmid, with no chromosomal involvement.

We are grateful to Dr P. M. Biggs, Mr R. Sampson, Miss Susan Shaw and Professor J. T. Smith for assistance in a variety of ways.

\section{REFERENCES}

ANDERSON, E. S. (1975). The problem and implications of chloramphenicol resistance in the typhoid bacillus. Journal of Hygiene 74, 289-299.

Butler, T., Linh, N. N., Arnold, K. \& Pollack, M. (1973). Chloramphenicol-resistant typhoid fever in Vietnam associated with $\mathbf{R}$ factor. Lancet ii, 983-985.

Center for Disease Control Weekly Report (1972). Typhoid fever-Mexico. Morbidity and Mortality 21, 177-178.

Lampe, R. M., Mansuwan, P. \& Duangmani, C. (1974). Chloramphenicol-resistant typhoid. Lancet i, 623-624.

LeDERBERG, J. \& LederberG, E. M. (1952). Replica plating and indirect selection of bacterial mutants. Journal of Bacteriology 63, 399-406.
Paniker, C. K. J. \& Vimala, K. N. (1972). Transferable chloramphenicol resistance in Salmonella typhi. Nature, London 239, 109-110.

Smith, H. Williams (1974). Thermosensitive transfer factors in chloramphenicol-resistant strains of S. typhi. Lancet ii, 281-282.

Smith, H. Williams (1978). Arsenic resistance in enterobacteria: its transmission by conjugation and by phage. Journal of General Microbiology $109,49-56$.

Smith, H. Williams, Parsell, Z. \& Green, P. (1978). Thermosensitive antibiotic resistance plasmids in enterobacteria. Journal of General Microbiology 109, 37-47. 